\title{
CATMAT statement on disseminated strongyloidiasis: Prevention, assessment and management guidelines
}

\author{
Boggild $\mathrm{AK}^{1,2,3}$, Libman $\mathrm{M}^{4}$, Greenaway $\mathrm{C}^{5}$, McCarthy $\mathrm{AE}^{6}$, on behalf of the Committee to Advise \\ on Tropical Medicine and Travel (CATMAT)*
}

\begin{abstract}
Background: Strongyloides stercoralis is a parasitic nematode found in humans, with a higher prevalence in tropical and sub-tropical regions worldwide. If untreated, the infection can progress to disseminated strongyloidiasis, a critical illness which may be fatal.
\end{abstract}

Objective: To provide clinical guidance on the prevention, assessment and management of disseminated strongyloidiasis.

Methods: A literature review was conducted to evaluate the current evidence and to identify any systematic reviews, case reports, guidelines and peer reviewed and non-peer reviewed medical literature. The Committee to Advise on Tropical Medicine and Travel (CATMAT) assembled a working group to develop this statement, which was then critically reviewed and approved by all CATMAT members.

Recommendations: CATMAT recommends that screening for strongyloidiasis should be considered for individuals with epidemiologic risk and/or co-morbidities that place them at risk for Strongyloides hyperinfection and dissemination. Those at highest risk of hyperinfection and dissemination are individuals born in a Strongyloides-endemic area who undergo iatrogenic immunosuppression or have intercurrent human T-lymphotropic virus (HTLV-1) infection. Diagnosis of strongyloidiasis is based on serologic testing and/or examination of stools and other clinical specimens for larvae. Referral to a tropical medicine specialist with expertise in the management of strongyloidiasis is recommended for suspected and confirmed cases. A diagnosis and treatment algorithm for strongyloidiasis has been developed as a reference tool.

Conclusion: Strongyloidiasis is relatively widespread in the global migrant population and screening for the disease should be based on an individual risk assessment. A practical tool for the clinician to use in the prevention, assessment and management of disseminated strongyloidiasis in Canada is now available.

\section{Affiliations}

${ }^{1}$ Tropical Disease Unit, Toronto General Hospital, University Health Network, Toronto, ON

2Department of Medicine, University of Toronto, Toronto, ON

${ }^{3}$ Public Health Ontario Laboratories, Toronto, ON

${ }^{4} J$. D. MacLean Centre for Tropical Disease, Division of Infectious Disease, Department of Microbiology, McGill University Health Centre, Montréal, QC

${ }^{5}$ Jewish General Hospital, Division of Infectious Diseases, Centre for Clinical Epidemiology, Lady Davis Institute for Medical Research, McGill University, Montréal, QC

${ }^{6}$ Tropical Medicine and International Health Clinic, Division of Infectious Disease, Ottawa Hospital General Campus, Ottawa, ON

\section{*Correspondence}

catmat.secretariat@phac-aspc. gc.ca

Suggested citation: Boggild AK, Libman M, Greenaway C, McCarthy AE, on behalf of the Committee to Advise on Tropical Medicine and Travel (CATMAT). CATMAT statement on disseminated strongyloidiasis: Prevention, assessment and management guidelines. Can Comm Dis Rep 2016;42:12-19. https://doi.org/10.14745/ ccdr.v42i01a03

\section{Preamble}

The Committee to Advise on Tropical Medicine and Travel (CATMAT) provides the Public Health Agency of Canada with ongoing and timely medical, scientific and public health advice relating to tropical infectious disease and health risks associated with international travel. The Agency acknowledges that the advice and recommendations set out in this statement are based upon the best current available scientific knowledge and medical practices and is disseminating this document for information purposes to both travellers and the medical community caring for travellers.
Persons administering or using drugs, vaccines or other products should also be aware of the contents of the product monograph(s) or other similarly approved standards or instructions for use. Recommendations for use and other information set out herein may differ from that set out in the product monograph(s) or other similarly approved standards or instructions for use by the licensed manufacturer(s). Manufacturers have sought approval and provided evidence as to the safety and efficacy of their products only when used in accordance with the product monographs or other similarly approved standards or instructions for use. 


\section{Introduction}

Strongyloidiasis is a disease caused by a nematode (i.e., a roundworm), which is present mainly in tropical and sub-tropical regions, but also in temperate climates. Precise data on prevalence are unknown in endemic countries; however, it is estimated that $30-100$ million people are infected worldwide (1). Most people who are infected with Strongyloides are asymptomatic and unaware of their infection; however, people who are immunosuppressed are at risk of developing the severe form of disseminated strongyloidiasis which, if untreated, can lead to potentially fatal illness (2). Although strongyloidiasis has traditionally been considered a tropical disease, increased worldwide travel and immigration have led to an increased number of cases seeking medical care in Canada.

The objectives of this statement are to:

1. Raise awareness of disseminated strongyloidiasis among clinicians who may encounter these cases (including front-line clinicians such as emergency room physicians, infectious diseases specialists, rheumatologists, dermatologists, gastroenterologists, oncologists, intensivists and transplant teams).

2. Assist clinicians in the prevention, assessment and management of disseminated strongyloidiasis.

\section{Methods}

This statement was created after CATMAT identified a need to inform Canadian clinicians about disseminated strongyloidiasis. A CATMAT working group was assembled and a member was elected to lead the statement development. The available literature was assessed for systematic reviews, guidelines, case reports and peer reviewed and non-peer reviewed medical literature. Based on the evidence compiled as well as expert opinion, a diagnosis and treatment algorithm for strongyloidiasis was designed as a reference tool for clinicians in Canada. The statement was then critically reviewed and approved by all CATMAT members.

\section{Epidemiology}

Strongyloides stercoralis is a parasitic nematode of humans, which is found throughout the tropics and subtropics worldwide. High prevalence of infection is found focally in the Caribbean, in West and East Africa and particularly Southeast Asia (3). Data support that anywhere between $10 \%$ to $40 \%$ of the population in tropical and sub-tropical regions are affected by strongyloidiasis, with rates as high as $60 \%$ in countries with ecologies and socioeconomic factors permissive to the transmission of S. stercoralis (3). A Canadian study of refugees documented a $77 \%$ seroprevalence among refugees from Cambodia and a $12 \%$ seroprevalence among refugees from Vietnam (4). Furthermore, strongyloidiasis was the fifth most common diagnosis among 1,321 ill new immigrants presenting for care at a Canadian Travel Medicine Network (CanTravNet) site over a three-year period $(5,6)$. Given that 6.8 million Canadians are foreign born, with approximately $85 \%$ emigrating from regions endemic for strongyloidiasis (7), a substantial proportion of the immigrant and refugee population of Canada is at risk for strongyloidiasis. Asia continues to be the largest source region for immigrants to Canada, with the Philippines, China and India serving as the top single source countries (7). Immigrant populations from Africa, the Caribbean, Central and South America are increasing over time as well (7).

In Canada, approximately 2.5-million individuals are estimated to have simple intestinal strongyloidiasis, assuming a source country prevalence of $40 \%$ (3). This estimate excludes travel-acquired strongyloidiasis, which is expected to account for a minority of cases in Canada. However, it is important to recognize that even short-term travel to highly endemic areas may be associated with acquisition of strongyloidiasis $(8,9,10)$.

It is difficult to estimate the proportion of Canadian immigrants and refugees who are at risk of developing disseminated strongyloidiasis, such as individuals who require iatrogenic immunosuppression or have HTLV1 co-infection.

\section{Pathogenesis}

Strongyloidiasis is acquired when infectious larvae, found in sand or soil, penetrate intact human skin and after an obligatory tissue migration phase, mature into adults in the small bowel. Unlike other parasitic helminths, Strongyloides has an indefinite lifespan in the human host and due to an autoinfection cycle whereby infective stage larvae re-penetrate host skin or bowel, clinical disease is a lifelong risk unless treated.

\section{Clinical features}

Strongyloides infection may cause a spectrum of illness ranging from asymptomatic eosinophilia to gastrointestinal symptoms to accelerated autoinfection (or "hyperinfection syndrome") to fulminant and fatal disseminated disease. Immune suppression such as that which occurs in the setting of prolonged corticosteroid therapy, HTLV-1 infection, or hematologic malignancy, is a risk factor for disseminated strongyloidiasis $(11,12,13,14)$, an entity documented to carry a mortality rate in excess of $85 \%(15,16)$. The exact mechanisms for immunologic control of this infection are unclear.

\section{Diagnosis and screening}

The Canadian Consortium on Refugee and Immigrant Health (CCRIH) has recently recommended Strongyloides screening only for refugees from Southeast Asia and Sub-Saharan Africa (17). Broader based screening was not recommended as there are little data on the prevalence of strongyloidiasis in immigrant populations and serologic screening is not easily or rapidly available in many parts of Canada. It has been our collective clinical experience, however, that strongyloidiasis is widespread in the global migrant population and screening should be based on a risk assessment, taking into account the risk of exposure to Strongyloides, the risk of disseminated disease and the presenting clinical syndrome (including asymptomatic persons who are planned to undergo iatrogenic immune suppression). This is supported by a case series in Toronto that documented ten cases of disseminated strongyloidiasis over 
a seven-month period, all of which occurred in immigrants to Canada, originating from Southeast Asia, the Caribbean, South America or Italy (11). Collectively, members of CATMAT have contributed to the care of patients with strongyloidiasis arising from travel to or residence in the Mediterranean, all parts of Africa, the Caribbean and Latin America, South Asia including the Indian subcontinent and the very high risk Southeast Asia. Thus, we recommend careful consideration of epidemiologic risk as outlined below in order to inform screening decisions.

Due to the low sensitivity of stool examination for ova and parasites (O\&P) arising from low larval burden and intermittent shedding in the stool, serologic testing is the diagnostic method of choice in the patient suspected to have simple intestinal strongyloidiasis.

It is important to note that sensitivity of serology may be reduced in the patient with immunosuppression, especially due to HTLV-1 infection or hematologic malignancy and associated chemotherapy $(18,19)$. These individuals are also at risk of developing disseminated strongyloidiasis and screening should generally involve both serologic and stool testing as outlined below. A stool O\&P sample that is positive for Strongyloides larvae should prompt screening for HTLV-1 infection and referral to a specialist in tropical medicine with expertise in the management of strongyloidiasis. Physician members of the Canadian Malaria Network are available to provide advice in such cases (20).

\section{Treatment}

The drug of choice for treatment of simple intestinal and asymptomatic strongyloidiasis is ivermectin $(15,21)$ given in two doses. Persons born or with prolonged residence in nations of the rainforest area of central Africa (e.g., Cameroon, Equatorial Guinea, Gabon, Central African Republic, Congo and the Democratic Republic of the Congo, as well as southern areas of Nigeria, Chad, South Sudan and northern Angola) should have high microfilaremic loiasis excluded prior to administration of ivermectin. This should be done by daytime blood film examination for microfilaria of Loa loa.

For Strongyloides hyperinfection or dissemination syndrome, CATMAT recommends dual-therapy with ivermectin and albendazole as outlined below, which is based on case report data $(11,22,23,24,25)$, expert opinion and the clinical experience of CATMAT members. Clinical specimens, including sputum and stool, should be rechecked periodically during the course of treatment of Strongyloides hyperinfection or dissemination to ensure clearance of larvae.

In order to prevent the development of disseminated strongyloidiasis, patients at risk for treatment failure or complications, such as those with HTLV-1 or Loa loa co-infection, should be referred to a tropical medicine specialist with expertise in the management of such infections. There is no evidence to support that a "test and treat" strategy is superior or more cost-effective compared to empiric administration of ivermectin to at risk individuals about to undergo immune suppression (26). As access to ivermectin is limited in Canada, CATMAT recommends that empiric treatment be reserved for individuals whose planned immune suppression cannot await diagnostic testing, as outlined in Step 3 of the diagnosis and treatment algorithm below.

Any patient with disseminated strongyloidiasis should also receive empiric treatment with broad-spectrum antibiotics to cover polymicrobial sepsis, a common complication of the hyperinfection syndrome. Both albendazole and ivermectin are pregnancy category $\mathrm{C}$ agents. In a pregnant person with Strongyloides hyperinfection or dissemination, the benefits of treatment likely outweigh the risks due to the life threatening nature of disseminated strongyloidiasis. Ivermectin and albendazole are only available in Canada through the Special Access Programme of Health Canada (27). Applications to the program typically have a one week turnaround time, although emergency use, same-day requests may be made by telephone.

\section{Infection control issues}

Patients with disseminated strongyloidiasis should be managed in contact precautions due to the risk of infectious filariform larvae being shed in effluents such as stool, urine, sputum and endotracheal aspirates. Most of these patients are critically unwell and require intensive nursing and medical care, thus precautions to prevent nosocomial transmission to health care workers is important. However, it must be noted that nosocomial transmission is a theoretical risk that has not been well documented in the literature $(28,29)$.

Contact precautions are also recommended for laboratory workers, due to the potential risk of encountering infectious filariform larvae, particularly in cultures of stool or sputum that have been sent to the laboratory to exclude bacterial infection. Agar plates of specimens from patients with disseminated strongyloidiasis should be handled with gloves and sealed with Parafilm ${ }^{\circledR}$ tape. Filariform larvae of other nematode helminths are susceptible to $70 \%$ ethanol for 10 minutes, $0.5 \%$ Dettol $^{\circledR}$ for 20 minutes and chlorinated hydrocarbons (tetrachloroethylene) (30). Filariform larvae can also be inactivated by water heated above $80^{\circ} \mathrm{C}(30)$. Household contacts of patients with disseminated strongyloidiasis or Strongyloides hyperinfection syndrome should be screened for strongyloidiasis serologically and by stool examination in order to identify person to person transmission.

\section{Diagnosis and treatment algorithm for strongyloidiasis - Steps 1-4}

Note to reader: All steps are to be completed sequentially, as Step 3 requires input from Steps 1 and 2 . 
Step 1: Define risk category for disseminated strongyloidiasis based on epidemiologic and clinical factors

\begin{tabular}{|c|c|c|}
\hline \multirow[b]{2}{*}{$\begin{array}{l}\text { Epidemiologic risk category for } \\
\text { Strongyloides exposure/Infection }\end{array}$} & \multicolumn{2}{|c|}{ Clinical risk factors for disseminated Strongyloides } \\
\hline & $\begin{array}{l}\text { - HTLV-1 }{ }^{1} \text { infection } \\
\text { - Glucocorticoid }{ }^{2} \text { therapy } \\
\text { - Immunomodulatory agent }{ }^{3} \\
\text { - Hematologic malignancy }\end{array}$ & $\begin{array}{l}\text { - No known defects in cell-mediated } \\
\text { immunity }\end{array}$ \\
\hline $\begin{array}{l}\text { Birth or residence or long-term travel } l^{4} \text { in Southeast Asia, } \\
\text { Oceania, Sub-Saharan Africa, South America, Caribbean }\end{array}$ & High & Moderate \\
\hline $\begin{array}{l}\text { Birth or residence or long-term trave }{ }^{4} \text { in Mediterranean } \\
\text { countries, Middle East, North Africa, Indian } \\
\text { sub-continent, Asia }\end{array}$ & Moderate & Low \\
\hline $\begin{array}{l}\text { Birth or residence or long-term travel }{ }^{4} \text { in Australia, North } \\
\text { America }{ }^{5} \text { or Western Europe }\end{array}$ & Very low & Very low \\
\hline
\end{tabular}

1 HTLV-1 = Human T-lymphotropic virus

2 Equivalent to $20 \mathrm{mg} /$ day of prednisone for $\geq 2$ weeks.

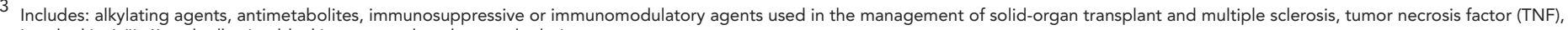

Interleokin 1 (IL-1) and adhesion blocking agents, lymphocyte depleting agents.

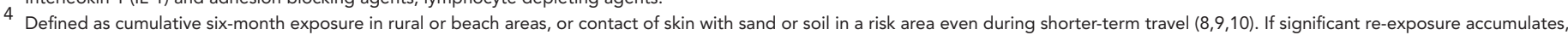
consider re-screening if initially negative.

5 Areas of North America that may be higher than low risk include Florida, Kentucky and Virginia. Aboriginal Australians are at elevated risk of strongyloidiasis.

\section{Step 2: Define suspected clinical syndrome}

\begin{tabular}{|c|c|c|}
\hline Suspected clinical syndrome & Appropriate diagnostic test & Appropriate diagnostic specimen \\
\hline $\begin{array}{l}\text { Asymptomatic } \pm \text { eosinophilia (This } \\
\text { would include asymptomatic individuals } \\
\text { undergoing planned immune } \\
\text { suppression.) } \\
\text { (Very low risk) }\end{array}$ & $\begin{array}{l}\text { - Serology } \\
\text { - Stool ova and parasites (O\&P) examination }\end{array}$ & $\begin{array}{l}\text { - Serum } \\
\text { - } \mathrm{SAF}^{4} \text {-preserved stool specimen }\end{array}$ \\
\hline $\begin{array}{l}\text { Simple intestinal strongyloidiasis }{ }^{1} \\
\text { (Low risk) }\end{array}$ & $\begin{array}{l}\text { - Serology } \\
\text { - Stool O\&P examination }\end{array}$ & $\begin{array}{l}\text { - Serum } \\
\text { - SAF-preserved stool specimen }\end{array}$ \\
\hline $\begin{array}{l}\text { Mild hyperinfection syndrome }{ }^{2} \\
\text { (Moderate risk) }\end{array}$ & $\begin{array}{l}\text { - Serology } \\
\text { - Stool O\&P examination } \\
\text { - Sputum O\&P examination } \\
\text { - Agar plate culture }\end{array}$ & $\begin{array}{l}\text { - Serum } \\
\text { - SAF-preserved stool specimen } \\
\text { - Fresh sputum in sterile container } \\
\text { - Fresh stool/sputum for agar plate culture }\end{array}$ \\
\hline $\begin{array}{l}\text { Disseminated strongyloidiasis }{ }^{3} \\
\text { (High risk) }\end{array}$ & $\begin{array}{l}\text { - Serology } \\
\text { - Stool O\&P examination } \\
\text { - Sputum O\&P examination } \\
\text { - Urine O\&P examination } \\
\text { - } \mathrm{CSF}^{5} \text { O\&P examination } \\
\text { - Tissue O\&P examination } \\
\text { - Agar plate culture }\end{array}$ & $\begin{array}{l}\text { - Serum } \\
\text { - SAF-preserved stool specimen } \\
\text { - Fresh sputum in sterile container } \\
\text { - Urine in sterile container } \\
\text { - CSF in sterile container } \\
\text { - Tissue, paraffin-embedded or unprocessed } \\
\text { - Any fresh specimen as above for agar plate } \\
\text { culture }\end{array}$ \\
\hline
\end{tabular}

1 Characterized by weight loss, abdominal discomfort and loose stools, with or without eosinophilia.

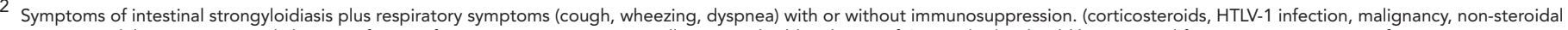
immunomodulating agents) and absence of signs of systemic toxicity or sepsis; all persons shedding larvae of Strongyloides should be screened for intercurrent HTLV-1 infection.

3 Severe clinical syndrome characterized by Gram-negative or polymicrobial sepsis and/or meningitis, with evidence of end-organ failure, including acute renal failure, acute respiratory distress, impaired consciousness, coma.

$4 \mathrm{SAF}=$ Sodium acetate-acetic acid-formalin

$5 \mathrm{CSF}=$ Cerebrospinal fluid 
Step 3: Suggested diagnostic and empiric management approach based on identified risk category (Step 1) and clinical syndrome (Step 2)

\begin{tabular}{|c|c|c|c|c|}
\hline \multirow{2}{*}{$\begin{array}{l}\text { Risk category } \\
\text { (as per Step 1) }\end{array}$} & \multicolumn{4}{|c|}{ Suspected clinical syndrome (as per Step 2) } \\
\hline & $\begin{array}{l}\text { Asymptomatic } \pm \\
\text { eosinophilia }^{1}\end{array}$ & $\begin{array}{l}\text { Simple intestinal } \\
\text { strongyloidiasis }\end{array}$ & $\begin{array}{l}\text { Mild hyperinfection } \\
\text { syndrome }\end{array}$ & $\begin{array}{l}\text { Disseminated } \\
\text { strongyloidiasis }\end{array}$ \\
\hline High & $\begin{array}{l}\text { Send appropriate } \\
\text { specimens for diagnostic } \\
\text { testing }{ }^{2} \\
\text { (Moderate risk) }\end{array}$ & $\begin{array}{l}\text { Empiric treatment while } \\
\text { awaiting diagnostic testing } \\
\text { (High risk) }\end{array}$ & $\begin{array}{l}\text { Empiric treatment while } \\
\text { awaiting diagnostic testing } \\
\text { (High risk) }\end{array}$ & $\begin{array}{l}\text { Empiric treatment while } \\
\text { awaiting diagnostic testing } \\
\text { (High risk) }\end{array}$ \\
\hline Moderate & $\begin{array}{l}\text { Send appropriate } \\
\text { specimens for diagnostic } \\
\text { testing } \\
\text { (Moderate risk) }\end{array}$ & $\begin{array}{l}\text { Send appropriate } \\
\text { specimens for diagnostic } \\
\text { testing } \\
\text { (Moderate risk) }\end{array}$ & $\begin{array}{l}\text { Empiric treatment while } \\
\text { awaiting diagnostic testing } \\
\text { (High risk) }\end{array}$ & $\begin{array}{l}\text { Empiric treatment while } \\
\text { awaiting diagnostic testing } \\
\text { (High risk) }\end{array}$ \\
\hline Low & $\begin{array}{l}\text { Send appropriate } \\
\text { specimens for diagnostic } \\
\text { testing } \\
\text { (Low risk) }\end{array}$ & $\begin{array}{l}\text { Send appropriate } \\
\text { specimens for diagnostic } \\
\text { testing } \\
\text { (Low risk) }\end{array}$ & $\begin{array}{l}\text { Send appropriate } \\
\text { specimens for diagnostic } \\
\text { testing } \\
\text { (Low risk) }\end{array}$ & $\begin{array}{l}\text { Send appropriate } \\
\text { specimens for diagnostic } \\
\text { testing } \\
\text { (Low risk) }\end{array}$ \\
\hline Very low & $\begin{array}{l}\text { Screening not } \\
\text { recommended. Consider } \\
\text { alternate diagnosis } \\
\text { (Very low risk) }\end{array}$ & $\begin{array}{l}\text { Screening not } \\
\text { recommended. Consider } \\
\text { alternate diagnosis } \\
\text { (Very low risk) }\end{array}$ & $\begin{array}{l}\text { Send appropriate } \\
\text { specimens for diagnostic } \\
\text { testing } \\
\text { (Very low risk) }\end{array}$ & $\begin{array}{l}\text { Send appropriate } \\
\text { specimens for diagnostic } \\
\text { testing } \\
\text { (Very low risk) }\end{array}$ \\
\hline
\end{tabular}

1 This includes asymptomatic individuals undergoing planned immune suppression.

2 In the rare circumstance where the patient is deemed high risk for strongyloidiasis and immunosuppression cannot await definitive diagnostic testing, we recommend empiric treatment with two doses of ivermectin as outlined in Step 4 below. 
Step 4: Treat strongyloidiasis according to clinical syndrome and diagnostic results

\begin{tabular}{|c|c|c|c|}
\hline Clinical syndrome & Diagnostic confirmation & Adult management & Pediatric management \\
\hline $\begin{array}{l}\text { Asymptomatic } \pm \text { eosinophilia } \\
\text { (including asymptomatic } \\
\text { individuals undergoing } \\
\text { planned immune suppression) } \\
\text { (Very low risk) }\end{array}$ & $\begin{array}{l}\text { - Serology } \\
\text { - Stool ova and parasites (O\&P) } \\
\text { examination for larvae }\end{array}$ & $\begin{array}{l}\text { Ivermectin } 200 \mu \mathrm{g} / \mathrm{kg} / \text { day po once } \\
\text { daily } \times 2 \text { doses on day } 1 \text { and } 2 \text {, or } \\
\text { 14-days apart }{ }^{1}\end{array}$ & $\begin{array}{l}\text { Ivermectin } 200 \mu \mathrm{g} / \mathrm{kg} / \text { day po once } \\
\text { daily } \times 2 \text { doses on day } 1 \text { and } 2 \text {, or } \\
\text { 14-days apart }\end{array}$ \\
\hline $\begin{array}{l}\text { Simple intestinal } \\
\text { strongyloidiasis }{ }^{2} \\
\text { (Low risk) }\end{array}$ & $\begin{array}{l}\text { - Serology } \\
\text { - Stool O\&P examination for } \\
\text { larvae }\end{array}$ & $\begin{array}{l}\text { Ivermectin } 200 \mu \mathrm{g} / \mathrm{kg} / \text { day po once } \\
\text { daily } \times 2 \text { doses on day } 1 \text { and } 2 \text {, or } \\
\text { 14-days apart }\end{array}$ & $\begin{array}{l}\text { Ivermectin } 200 \mu \mathrm{g} / \mathrm{kg} / \text { day po once } \\
\text { daily } \times 2 \text { doses on day } 1 \text { and } 2 \text {, or } \\
\text { 14-days apart }{ }^{1}\end{array}$ \\
\hline $\begin{array}{l}\text { Mild hyperinfection } \\
\text { syndrome } \\
\text { (Moderate risk) }\end{array}$ & $\begin{array}{ll}\text { - } & \text { Serology } \\
\text { - Stool O\&P } \\
\text { - Sputum O\&P examination for } \\
\text { larvae }\end{array}$ & $\begin{array}{l}\text { Ivermectin } 200 \mu \mathrm{g} / \mathrm{kg} / \text { day po once } \\
\text { daily } \times 2 \text { doses on day } 1 \text { and } 2 \text {, or } \\
\text { 14-days apart }{ }^{1} \\
\text { PLUS } \\
\text { Albendazole } 400 \mathrm{mg} \text { po BID x } \\
7 \text { days } \\
\text { OR, Monotherapy: } \\
\text { Ivermectin } 200 \mu \mathrm{g} / \mathrm{kg} / \text { day po once } \\
\text { daily } x 7 \text { days }\end{array}$ & $\begin{array}{l}\text { Ivermectin } 200 \mu \mathrm{g} / \mathrm{kg} / \text { day po once } \\
\text { daily } \times 2 \text { doses on day } 1 \text { and } 2 \text {, or } \\
\text { 14-days apart } \\
\text { PLUS } \\
\text { Albendazole } 400 \mathrm{mg} \text { po BID x } \\
7 \text { days } \\
\text { OR, Monotherapy: } \\
\text { Ivermectin } 200 \mu \mathrm{g} / \mathrm{kg} / \text { day po once } \\
\text { daily } \times 7 \text { days }\end{array}$ \\
\hline $\begin{array}{l}\text { Disseminated strongyloidiasis } \\
4,5 \\
\text { (High risk) }\end{array}$ & $\begin{array}{l}\text { - Serology } \\
\text { - Stool O\&P examination for } \\
\text { larvae } \\
\text { - Sputum O\&P examination for } \\
\text { larvae } \\
\text { - Urine, cerebrospinal fluid (CSF) } \\
\text { or other body fluid or tissue } \\
\text { examination for larvae. }\end{array}$ & $\begin{array}{l}\text { Ivermectin } 200 \mu \mathrm{g} / \mathrm{kg} / \text { day po or } \mathrm{sc}^{6} \\
\text { once daily } \\
\text { PLUS } \\
\text { Albendazole } 400 \mathrm{mg} \text { po BID until } \\
\text { cessation of larval shedding and } \\
\text { clinical improvement }\end{array}$ & $\begin{array}{l}\text { Ivermectin } 200 \mu \mathrm{g} / \mathrm{kg} / \text { day po or } \mathrm{sc}^{6} \\
\text { once daily } \\
\text { PLUS } \\
\text { Albendazole } 400 \mathrm{mg} \text { po BID until } \\
\text { cessation of larval shedding and } \\
\text { clinical improvement }\end{array}$ \\
\hline
\end{tabular}

1 A 14-day dosing interval is preferred due to the risk of prepatent infection arising from autoinfection (15).

2 Characterized by weight loss, abdominal discomfort and loose stools, with or without eosinophilia.

3 Symptoms of intestinal strongyloidiasis plus respiratory symptoms (cough, wheezing, dyspnea) with or without immunosuppression (corticosteroids, HTLV-1 infection, malignancy, non-steroidal

immunomodulating agents) and absence of signs of systemic toxicity or sepsis; all persons shedding larvae of Strongyloides should be screened for intercurrent HTLV-1 infection

4 Severe clinical syndrome characterized by Gram-negative or polymicrobial sepsis and/or meningitis, with evidence of end-organ failure, including acute renal failure, acute respiratory distress, impaired consciousness, coma.

5 Patients with disseminated strongyloidiasis should also receive empiric coverage of polymicrobial sepsis with broad-spectrum antibiotics.

6 Available only as a veterinary formulation; use in humans is off-label and not Health Canada approved $(25,31,32,33)$ 


\section{Conclusion}

Strongyloidiasis is relatively widespread in the global migrant population. Screening for the disease should be based on an individual risk assessment, taking into account the risk of exposure to Strongyloides, the risk of disseminated disease and the presenting clinical syndrome (which may include asymptomatic persons who are planned to undergo iatrogenic immune suppression). This statement summarizes the available relevant information on strongyloidiasis and provides a practical tool for the clinician to use in the prevention, assessment and management of disseminated strongyloidiasis in Canada.

\section{Key points}

- $\quad$ Screening for strongyloidiasis should be considered for individuals with epidemiologic risk and/or comorbidities that place them at risk for Strongyloides hyperinfection and dissemination. Those at highest risk of hyperinfection and dissemination are individuals born in a Strongyloidesendemic area who undergo iatrogenic immunosuppression, or have intercurrent HTLV-1 infection.

- Diagnosis of strongyloidiasis rests on serologic testing and/ or examination of stools and other clinical specimens for larvae. Serology is generally highly sensitive, while stool examination is highly specific.

- Performance characteristics of diagnostic tests may be altered by immune suppression and coinfections such as HTLV-1, in that stool examination sensitivity may improve, while sensitivity of serology may decline.

- Referral to a tropical medicine specialist with expertise in the management of strongyloidiasis is recommended for any patient with suspected or confirmed disseminated strongyloidiasis and for patients with both Strongyloides and HTLV-1 or Loa loa infections.

\section{Acknowledgements}

CATMAT acknowledges and appreciates the contribution of Mihaela Gheorghe.

CATMAT members: McCarthy A (Chair), Boggild A, Brophy J, Bui Y, Crockett M, Greenaway C, Libman M, Teitelbaum P and Vaughan S.

Liaison members: Audcent T (Canadian Paediatric Society), Gershman M (United States Centers for Disease Control and Prevention) and Pernica J (Association of Medical Microbiology and Infectious Disease Canada).

Ex officio members: Marion D (Canadian Forces Health Services Centre, Department of National Defence), McDonald P (Division of Anti-Infective Drugs, Health Canada), Schofield S (Pest Management Entomology, Department of National Defence) and
Tepper M (Directorate of Force Health Protection, Department of National Defence).

\section{Conflict of interest}

None.

\section{Funding}

This work was supported by the Public Health Agency of Canada.

\section{References}

1. World Health Organization.Intestinal Worms: Strongyloidiasis. Geneva: WHO; 2015. http://www.who.int/ intestinal_worms/epidemiology/strongyloidiasis/en.

2. Centers for Disease Control and Prevention. Parasites Strongyloides. Epidemiology and risk factors. Atlanta GA: CDC; 2015. http://www.cdc.gov/parasites/strongyloides/epi. html.

3. Schär F, Trostdorf U, Giardina F, Khieu V, Muth S, Marti H, et al. Strongyloides stercoralis: Global distribution and risk factors. PLoS Negl Trop Dis. 2013;7(7):e2288.

4. Gyorkos TW, Genta RM, Viens P, MacLean JD. Seroepidemiology of Strongyloides infection in the Southeast Asian refugee population in Canada. Am J Epidemiol. 1990;132:257-64.

5. Boggild AK, Geduld J, Libman M, McCarthy A, Vincelette J, Ghesquiere W, Hajek J, Kuhn S, Freedman DO, Kain KC. Travel-acquired infections in Canada: CanTravNet 2011 2012. Can Commun Dis Rep. 2014;40(16):313-325.

6. Boggild AK, Geduld J, Libman M, Ward B, McCarthy A, Doyle P, Ghesquiere W, Vincelette J, Kuhn S, Freedman DO, Kain KC. Travel-acquired infections and illnesses in Canadians: Surveillance report from CanTravNet surveillance data, 2009 - 2011. Open Med. 2014;8(1):e20-e32.

7. Statistics Canada. Immigration and ethnocultural diversity in Canada. National Household Survey, 2011. Ottawa ON: Minister of Industry; 2015. http://www12.statcan.gc.ca/nhsenm/2011/as-sa/99-010-x/99-010-x2011001-eng.pdf.

8. Baaten GG, Sonder GJ, van Gool T, et al. Travel-related schistosomiasis, strongyloidiasis, filariasis, and toxocariasis: The risk of infection and the diagnostic relevance of blood eosinophilia. BMC Infect Dis. 2011;11:84.

9. Angheben A, Mistretta M, Gobbo M, Bonafini S, lacovazzi T, Sepe A, Gobbi F, Marocco S, Rossanese A, Bisoffi Z. Acute strongyloidiasis in Italian tourists returning from Southeast Asia http://www.ncbi.nlm.nih.gov/pubmed/21366799. J Travel Med. 2011 Mar-Apr;18(2):138-40.

10. Bailey KE, Danylo A, Boggild AK. Chronic larva currens following tourist travel to the Gambia and Southeast Asia over 20 years ago. J Cutan Med Surg. 2015;19(4):412-5. 
11. Lim S, Katz K, Kradjen S, Fuksa M, Keystone JS, Kain KC. Complicated and fatal Strongyloides infection in Canadians: Risk factors, diagnosis, and management. CMAJ. 2004;171(5):479-84.

12. Rogers WA Jr, Nelson B. Strongyloidiasis and malignant lymphoma "opportunistic infection" by a nematode. JAMA. 1966;195:685-7.

13. Willis AJP, Nwokolo C. Steroid therapy and strongyloidiasis. Lancet. 1966;1:1396-8.

14. Cruz R, Reboucas G, Rocha H. Fatal strongyloidiasis in patients receiving corticosteroids. N Engl J Med. 1966;275:1093-6.

15. Suputtamongkol $Y$, Premasathian N, Bhumimuang $K$, Waywa D, Nilganuwong S, Karuphong E, et al. Efficacy and safety of single and double doses of ivermectin versus seven-day high dose albendazole for chronic strongyloidiasis. PLoS Negl Trop Dis. 2011;5(5):e1044.

16. Igra-Siegman $Y$, Kapila R, Sen P, Kaminski ZC, Louria DB. Syndrome of hyperinfection with Strongyloides stercoralis. Rev Infect Dis. 1981;3:397-407.

17. Pottie K, Greenaway C, Feightner J, Welch V, Swinkels $H$, Rashid $M$, et al. Evidence-based clinical guidelines for immigrants and refugees. CMAJ Can Med Assoc J. 2011;183(12):E824-E925.

18. Porto AF, Oliveira Filho J,Neva FA, Orge G, Alcântara, Gam A, Carvalho EM, Influence of human T-cell lymphocytotropic virus type 1 infection on serologic and skin tests for strongyloidiasis. Am J Trop Med Hyg .2001 Nov;65(5):610-3.

19. Schaffel R, Nucci M, Carvalho E, Braga M, Almeida L, Portugal R, Pulcheri W. The value of an immunoenzymatic test (enzyme-linked immunosorbent assay) for the diagnosis of strongyloidiasis in patients immunosuppressed by hematologic malignancies. Am J Trop Med Hyg http://www. ncbi.nlm.nih.gov/pubmed/11693882. 2001 Oct;65(4):346-50.

20. Public Health Agency of Canada. Canadian Malaria Network (CMN) http://www.phac-aspc.gc.ca/tmp-pmv/quinine/indexeng.php.

21. Meunnig P, Pallin D, Challah C, Khan K. The costeffectiveness of ivermectin vs. albendazole in the presumptive treatment of strongyloidiasis in immigrants to the United States. Epidemiol Infect. 2004;132:1055-1063.

22. Balagopal A, Mills L, Shah A, Subramanian A. Detection and treatment of Strongyloides hyperinfection syndrome following lung transplantation. Transpl Infect Dis. 2009;11:149-154.

23. Altintop L, Cakar B, Hokelek M, Bektas A, Yildiz L, Karaoglanoglu M. Strongyloides stercoralis hyperinfection in a patient with rheumatoid arthritis and bronchial asthma: A case report. Ann Clin Microbiol Antimicrob. 2010;9:27.

24. Hasan A, Le M, Pasko J, Ravin KA, Clauss H, Hasz R, et al. Transmission of Strongyloides stercoralis through transplantation of solid organs - Pennsylvania, 2012. MMWR Morbid Mortal Wkly Rep. 2013;62(14):264-266.

25. Chiodini PL, Reid AJC, Wiselka MJ, Firmin R, Foweraker J. Parenteral ivermectin in Strongyloides hyperinfection. Lancet. 2000;355:43-44.
26. Roxby AC, Gottlieb GS, Limaye AP. Strongyloidiasis in transplant patients. Clin Infect Dis. 2009;49:1411-1423.

27. Health Canada. Guidance document for industry and practitioners: Special access programme for drugs. Ottawa ON: Health Canada; 2013. http://www.hc-sc.gc.ca/dhp-mps/ alt_formats/hpfb-dgpsa/pdf/acces/sapg3_pasg3-eng.pdf.

28. Maraha B, Buiting AGM, Hol C, Pelgrom R, Blotkamp C, Polderman AM. The risk of Strongyloides stercoralis transmission from patients with disseminated strongyloidiasis to the medical staff. J Hosp Infect. 2001;49:222-224.

29. Hauber HP, Galle J, Chiodini PL, Rupp J, Birke R, Vollmer E, Zabel P, Lange C. Fatal outcome of a hyperinfection syndrome despite successful eradication of Strongyloides with subcutaneous ivermectin. Infect. 2005;33(5/6):383-386.

30. Public Health Agency of Canada. Ancylostoma duodenale. Pathogen safety data sheet - infectious substances. Ottawa ON: PHAC; 2012. http://www.phac-aspc.gc.ca/lab-bio/res/ psds-ftss/ancylostoma-duodenale-eng.php.

31. Turner SA, Maclean JD, Fleckenstein L, Greenaway C. Parenteral administration of ivermectin in a patient with disseminated strongyloidiasis. Am J Trop Med Hyg. 2005;73(5):911-914.

32. Leung $\mathrm{V}$, Al-Rawahi GN, Grant J, Fleckenstein L, Bowie W. Case report: Failure of subcutaneous ivermectin in treating Strongyloides hyperinfection. Am J Trop Med Hyg. 2008;79(6):853-855.

33. Salluh JIF, Feres GA, Velasco E, Holanda GS, Toscano $L$, Soares M. Successful use of parenteral ivermectin in an immunosuppressed patient with disseminated strongyloidiasis and septic shock. Intensive Care Med. 2005;31:1292. 